\title{
PEMANFAATAN EMBUNG SAMBIREJO KABUPATEN SRAGEN SEBAGAI SARANA PEMENUHAN KEBUTUHAN AIR NON IRIGASI
}

\author{
Chrisna Justice Wicaksana $^{1}$, Adi Yusuf Muttaqien ${ }^{2}$ dan Rr Rintis Hadiani ${ }^{3}$ \\ Program Studi Teknik Sipil, Universitas Sebelas Maret, Jl. Ir. Sutami 36 A Surakarta \\ Email: ${ }^{1}$ chrisnajustice@gmail.com, 2ayusmut@yahoo.co.id, ${ }^{3}$ rintisha@gmail.com
}

\begin{abstract}
Drought is a state of water shortage in an area for prolonged periods (months to years). Usually this event occurs when a region continuously experiences below average rainfall. Utilization and development of water resources through rain harvesting can be maximized to improve the efficiency of water utilization in dry land or areas susceptible to waterlogging. The rational method is the formula used to calculate the peak discharge of a stream or channel but with a finite drainage region. According to Goldman (1986) in Suripin (2004), the Rational Method can be used for drainage areas <300 ha. According to Ponce (1989) in Bambang Triatmodjo (2008), Rational Method can be used for drainage area $<2.5 \mathrm{~km} 2$. In the Department of Public Works, SK SNI M18-1989-F (1989), explained that the Rasinal Method can be used for the size of the drainage area $<5000$ ha. This study is to analyze the volume that can be used to collect rain water. The method used in this research is quantitative descriptive research by doing the debit calculation plan, using the Rational method to determine the peak discharge on the embung that will be used to meet the needs of domestic (domestic) in Sambirejo Village, Sragen regency, Central Java. The results showed that the rainfall that happened in Sambirejo Village of Sragen Regency was calculated by rational method that is equal to 4774,064 m3 / dt, water loss of 1909,626 m3 / dt, and the discharge was 2864,439 m3 / dt. The volume of embung storage in Sambirejo Village of Sragen regency is $5000 \mathrm{~m} 3$ with domestic requirement of 2864,35 $\mathrm{m3} / \mathrm{s}$, non domestic requirement equal to $859,31 \mathrm{~m} 3 / \mathrm{dt}$, and requirement of livestock equal to 257,79 $\mathrm{m3} /$ And the projected requirement up to 2025 is domestic requirement of 545,20 m3 / $s$, non domestic requirement equal to $163,56 \mathrm{~m} 3 / \mathrm{dt}$, and requirement of livestock equal to $49,07 \mathrm{~m} 3 / \mathrm{dt}$.
\end{abstract}

Keywords: retention basin, rain harvest, rational method, Sambirejo Village, domestic requirement

\begin{abstract}
ABSTRAK
Kekeringan adalah keadaan kekurangan pasokan air pada suatu daerah dalam masa yang berkepanjangan (beberapa bulan hingga bertahun-tahun). Biasanya kejadian ini muncul bila suatu wilayah secara terus-menerus mengalami curah hujan di bawah rata-rata. Pemanfaatan dan pengembangan sumberdaya air melalui panen hujan dapat dimaksimalkan untuk meningkatkan efisiensi pemanfaatan air di lahan kering atau wilayah yang rentan tergenang air. Metode rasional merupakan rumus yang digunakan untuk menghitung debit puncak sungai atau saluran namun dengan daerah pengaliran terbatas. Menurut Goldman (1986) dalam Suripin (2004), Metode Rasional dapat digunakan untuk daerah pengaliran < 300 ha. Menurut Ponce (1989) dalam Bambang Triatmodjo (2008), Metode Rasional dapat digunakan untuk daerah pengaliran $<2,5 \mathrm{~km}^{2}$. Dalam Departemen PU, SK SNI M-18-1989-F (1989), dijelaskan bahwa Metode Rasinal dapat digunakan untuk ukuran daerah pengaliran $<5000$ ha. Penelitian ini adalah dengan melakukan analisis volume yang dapat digunakan embung untuk menampung air hujan. Metode yang digunakan dalam penelitian ini adalah penelitian deskriptif kuantitatif dengan melakukan perhitungan debit rencana, menggunakan metode Rasional untuk menentukan debit puncak pada embung yang akan digunakan untuk memenuhi kebutuhan rumah tangga (domestik) di Desa Sambirejo Kabupaten Sragen JawaTengah. Hasil penelitian menunjukkan bahwa debit hujan yang terjadi di Desa Sambirejo Kabupaten Sragen berdasarkan perhitungan dengan metode rasional yaitu sebesar 4774,064 m³/ dt, kehilangan air sebesar 1909,626 $\mathrm{m}^{3} / \mathrm{dt}$, dan debit tersedia sebesar 2864,439 $\mathrm{m}^{3} / \mathrm{dt}$. Volume simpanan embung di Desa Sambirejo Kabupaten Sragen sebesar $5000 \mathrm{~m}^{3}$ dengan kebutuhan domestik sebesar 2864,35 m³/dt, kebutuhan non domestik sebesar $859,31 \mathrm{~m}^{3} / \mathrm{dt}$, dan kebutuhan ternak sebesar 257,79 m³/dt. Dan proyeksi kebutuhan hingga tahun 2025 adalah kebutuhan domestik sebesar 545,20 m³/dt, kebutuhan non domestik sebesar 163,56 m²/dt, dan kebutuhan ternak sebesar 49,07 $\mathrm{m}^{3} / \mathrm{dt}$.
\end{abstract}

Kata kunci: embung tadah hujan, panen hujan, metode rasional, Desa Sambirejo, kebutuhan domestik 


\section{PENDAHULUAN}

Kekeringan dapat menjadi bencana alam apabila mulai menyebabkan suatu wilayah kehilangan sumber pendapatan akibat gangguan pada pertanian dan ekosistem yang ditimbulkannya. Dampak ekonomi dan ekologi kekeringan merupakan suatu proses sehingga batasan kekeringan dalam setiap bidang dapat berbeda-beda. Namun demikian, suatu kekeringan yang singkat tetapi intensif dapat pula menyebabkan kerusakan yang signifikan. (Putri Ayu, 2011) Air adalah kebutuhan dasar untuk kebutuhan manusia, terutama untuk digunakan sebagai air minum, memasak makanan, mencuci, mandi, dan sanitasi. Ketersediaan air bersih merupakan hal yang selayaknya diprioritaskan oleh pemerintah untuk memenuhi kebutuhan masyarakat baik di perkotaan maupun di pedesaan. Pada umumnya sumber air yang tersedia saat ini berasal dari sungai, sumur air tanah dangkal, maupun PDAM. Salah satu alternatif yang dapat digunakan sebagai upaya untuk menanggulangi kekeringan adalah pemanenan air hujan (rainwater harvesting). Pemanenan air hujan adalah suatu teknik yang mengumpulkan dan menampung air hujan ke suatu tangki atau waduk alami, atau peresapan air permukaan ke akuifer di bawah permukaan (sebelum jadi limpasan permukaan). Pemanenan air hujan sudah banyak dilakukan sejak lama khususnya di pedesaan dimana sumber air lainnya yaitu air tanah tidak mencukupi, atau pengadaannya terlalu mahal. Pemanenan air hujan dilakukan untuk memenuhi kebutuhan rumah tangga dan ternak, terutama menjelang dan selama musim kemarau panjang. Cara yang dilakukan yaitu dengan pengumpulan air hujan yang mengucur dari atap rumah. Untuk skala besar pemanenan air hujan dapat dilakukan di daerah tangkapan air. (Taufik Imam Rohadi, 2014).

\section{TINJAUAN PUSTAKA DAN LANDASAN TEORI}

\section{Pemanenan Air Hujan}

Pemanenan air hujan adalah suatu teknik yang mengumpulkan dan menampung air hujan ke suatu tangki atau waduk alami, atau peresapan air permukaan ke akuifer di bawah permukaan (sebelum jadi limpasan permukaan). Pemanenan air hujan merupakan upaya manusia dalam mengatasi kekurangan kebutuhan air bersih sehingga bermanfaat untuk masyarakat. Pemanenan air hujan dapat dilakukan dengan media alami maupun buatan.

\section{Embung}

Embung atau cekungan penampung (retention basin) adalah cekungan yang digunakan uuntuk mengatur dan menampung suplai aliran air hujan serta untuk meningkatkan kualitas air. (https:id.wikipedia.org/wiki/Embung)

\section{Neraca Air}

Neraca Air merupakan suksesi tahapan-tahapan yang dilalui air dari atmosfir ke bumi dan kembali lagi ke atmosfer (Seyhan, 1990). Ketersediaaan air pada embung bergantung pada nilai komponen neraca air, yaitu penguapan dari air permukaan, rembesan samping dari dinding embung dan perkolasi dari dasar embung. Jadi untuk memperbaiki desain embung diperlukan evaluasi neraca air. Kehilangan air total karena penguapan, rembesan, dan perkolasi adalah sekitar $40 \%$ dari total simpanan air. Persentase penguapan, rembesan, dan perkolasi masing-masing adalah 40\%, 26\%, dan 34\% dari total kehilangan air. (Hermantono, 2011).

\section{Peta Topografi}

Peta topografi yaitu peta yang menyajikan data dan informasi keadaan lapangan secara menyeluruh yang sifatnya umum, baik itu unsur alam (sungai, gunung, danau, laut, dan lain-lain) maupun unsur buatan (jalan, jembatan, perkampungan, bendungan, dan lain-lain) dengan garis bayangan ketinggian (garis kontur ketinggian) dalam perbandingan tertentu (skala) (Lemdiknas, 2005).

\section{DAS}

DAS (Daerah Aliran Sungai) adalah daerah dimana semua airnya mengalir ke dalam suatu sungai yang dimaksudkan. Daerah ini umumnya dibatasi oleh batas topografi, yang berarti ditetapkan berdasarkan pada aliran permukaan, dan bukan ditetapkan berdasarkan pada air bawah tanah karena permukaan air tanah selalu berubah sesuai dengan musim dan tingkat kegiatan pemakaian (Sharon Marthina Rapar, 2014).

\section{Data Hujan}

Data hujan merupakan data yang dibutuhkan dalam penelitian dan penanganan masalah banjir. Pengukuran hujan dilakukan oleh instansi terkait dengan menggunakan alat ukur penakar hujan (Nuansah Fidiawan, 2013). 
Pengukuran tersebut dilakukan di stasiun penakar hujan (stasiun hujan) sehingga merupakan hujan yang terjadi pada suatu titik. Dalam penelitian ini hujan yang digunakan adalah hujan wilayah dengan menganalisis data hujan dari dua stasiun hujan, yaitu Stasiun Hujan Munggur dan Stasiun Hujan Batujamus dengan rentang tahun 2001 2015.

\section{Pengisian Data Hujan Yang Hilang}

Pengisian data yang hilang dapat dilakukan dua metode, yaitu Normal Ratio Method dan Reciprocal Method. Dalam penelitian ini, pengisian data yang hilang menggunakan Reciprocal Method yang dapat dilihat pada Persamaan (1).

$P_{x}=\frac{\sum_{i=1}^{n} \frac{P_{i}}{L_{i}^{2}}}{\sum_{i=1}^{n} \frac{l}{L}}$

dengan :

$P_{(x)}=$ data hujan yang hilang di stasiun $X(\mathrm{~mm})$,

$P_{(i)}=$ data hujan di stasiun sekitarnya pada kala yang sama (mm),

$L_{(i)}=$ jarak stasiun X dengan stasiun di sekitarnya $(\mathrm{km})$,

$n=$ jumlah stasiun hujan di sekitarnya.

\section{Uji Konsistensi}

Uji konsistensi yang digunakan dalam penelitian ini adalah metode kurva massa ganda (double mass curve) yang dapat dilihat pada Persamaan (2).

$\mathrm{Hz}=\frac{\tan \alpha 1}{\tan \alpha 2}$

Tingkat korelasi antar stasiun hujan yang digunakan dapat diketahui dengan menghitung harga $\mathrm{R}$ menggunakan

Persamaan (3).

$\mathrm{r}=\frac{n \sum x y-\left(\sum x\right)\left(\sum y\right)}{\sqrt{\left(n \sum x^{2}-\left(\sum x\right)^{2}\right)\left(n \sum y^{2}-\left(\sum y\right)^{2}\right)}}$

\section{Hujan Wilayah}

Untuk menentukan hujan wilayah, dapat dipergunakan berbagai metode seperti metode rerata, poligon Thiessen dan Ishoyet. Dalam penelitian ini, metode yang digunakan adalah metode rerata aritmatik (aljabar) yang dapat dilihat pada Persamaan (4).

$$
P=\frac{\sum_{i=1}^{n} P_{i}}{n}
$$

dengan :

$P=$ hujan rerata kawasan,

$P_{n}=$ curah hujan yang tercatat di pos penakar,

$n=$ banyaknya pos penakar.

\section{Pengukuran Dispersi}

Dalam analisis hidrologi pengukuran dispersi dibutuhkan untuk menentukan jenis sebaran data yang sesuai dengan data hujan. Pengukuran dispersi dari perhitungan adalah Standar Deviasi (S), Koefisien Variasi (Cv), Pengukuran Kurtosis (Ck) dan Koefisien Kemencengan (Cs), yang dapat dilihat pada Persamaan (5), (6), (7), (8)

$S=\sqrt{\frac{1}{n-1} \sum_{i=1}^{n} x_{i}-\bar{x}^{2}}$

dengan :

$S=$ standar deviasi,

$x_{i}=$ nilai varian,

$\bar{x}=$ curah hujan rata-rata,

$n=$ jumlah data.

$C v=\frac{S}{\bar{x}}$

dengan :

$C v=$ koefisieen variasi,

$S=$ standar deviasi, 
$\bar{x}=$ nilai rata-rata.

$C s=\frac{a}{s^{3}}$

$a=\frac{n}{(n-1)(n-2)} \sum_{i=1}^{n}\left(x_{i}-\bar{x}\right)^{3}$

dengan:

$C s=$ koefisien kemencengan,

$S=$ standar deviasi,

$x_{i}=$ nilai varian,

$\bar{x}=$ rata-rata hitung,

$n=$ jumlah data.

$C k=\frac{n^{2}}{(n-1)(n-2)(n-3) S^{2}} \sum_{i=1}^{n}\left(x_{i}-\bar{x}\right)^{4}$

dengan :

$C k=$ koefisien kurtois,

$S=$ standar deviasi,

$x_{i}=$ nilai varian,

$\bar{x}=$ rata-rata hitung,

$n=$ jumlah data.

\section{Perhitungan Hujan Kala Ulang}

Dalam penelitian ini, perhitungan hujan kala ulang menggunakan Distribusi Log Pearson III yang dapat dilihat pada Persamaan (9)

$\log X_{t}=\log X_{r t}+$ k.S

$X_{t}=10^{\log X t}$

dengan :

$X t=$ curah hujan rencana,

$X r t=$ curah hujan rata-rata,

$k=$ koefisien distribusi pearson,

$S=$ standar deviasi.

\section{Pengujian Kecocokan Sebaran}

Analisis pada penelitian ini menggunakan uji kecocokan Smirnov-Kolmogorov. Pengujian dilakukan dengan cara membandingkan probabilitas pada tiap-tiap variabel dari suatu distribusi yang hasilnya akan didapat perbedaan $(\Delta)$. Perbedaan maksimum $\left(\Delta_{\text {maks }}\right)$ yang dihitung dibandingkan dengan perbedaan kritis $\left(\Delta_{\text {cr }}\right)$ untuk banyaknya varian tertentu. Sebaran dikatakan sesuai jika $\Delta_{\text {maks }}<\Delta_{\text {cr }}$ (Soewarno, 1995).

\section{Distribusi Hujan}

Analisis intensitas durasi frekuensi (IDF) dilakukan untuk memperkirakan debit aliran puncak berdasar data hujan titik. Salah satu metode untuk memperkirakan waktu konsentrasi adalah rumus yang dikembangkan oleh Kirpich yang dapat dilihat pada Persamaan (10)

$t_{c}=\left(\frac{0,87 \times L^{2}}{1000 \times S}\right)^{0,385}$

dengan :

$t c=$ waktu konsentrasi (jam),

$L=$ panjang saluran utama $(\mathrm{km})$,

$S=$ kemiringan rata-rata saluran $(\mathrm{m} / \mathrm{m})$.

\section{Metode Rasional}

Metode rasional merupakan rumus yang digunakan untuk menghitung debit puncak sungai atau saluran namun dengan daerah pengaliran terbatas, rumus dari Metode Rasional yang dapat dilihat pada Persamaan (11)

$\mathrm{Q}=0,278 \times \mathrm{C} \times \mathrm{I} \times \mathrm{A}$

dengan :

$Q=$ debit puncak $\left(\mathrm{m}^{3} /\right.$ deik $)$, 
$C=$ angka pengaliran $(\mathrm{km})$,

$I=$ intensitas hujan $(\mathrm{mm} / \mathrm{jam})$,

$A=$ luas DAS $\left(\mathrm{km}^{2}\right)$.

\section{Kebutuhan Domestik}

Kebutuhan air untuk keperluan rumah tangga (domestik) meliputi semua kebutuhan air untuk keperluan penghuni. Seperti kebutuhan air untuk memasak, toilet, mencuci, mandi, dan berkebun. Tingkat kebutuhan air bervariasi berdasarkan keadaan alam di area pemukiman, banyaknya penghuni rumah, karakteristik penghuni serta ada atau tidaknya penghitung pemakaian. (Kindler and Russel, 1984).

\section{METODE PENELITIAN}

Lokasi penelitian ini berada di Desa Sambirejo Kabupaten Sragen. Wilayah ini masuk dalam DAS Bengawan Solo yang memiliki luas sebesar $\pm 21 \mathrm{~km}^{2}$. Dalam melakukan penelitian, beberapa data yang diperlukan berupa data hujan Stasiun Batu Jamus, dan Stasiun Munggur Kabupaten Sragen pada tahun 2001-2015 yang diperoleh dari Balai Pengelola Sumber Daya Air Bengawan Solo (BPSDA Bengawan Solo), peta Topografi DAS Bengawan Solo skala 1 : 25.000 yang diperoleh dari Badan Informasi Geospasial (BIG), peta stasiun hujan DAS Bengawan Solo yang diperoleh dari Balai Pengelola Sumber Daya Air Bengawan Solo (BPSDA Bengawan Solo), data pengukuran embung Desa Sambirejo yang diperoleh dari hasil survei lapangan pada tanggal 16-18 Maret 2017. Analisis data dilakukan dengan bantuan Microsoft Excel, Microsoft Word, Auto CAD, dan Google Earth.

Tahapan penelitian yang pertama dilakukan adalah mengumpulkan data-data yang dibutuhkan seperti data hujan, data pengukuran embung, peta topografi dan jumlah penduduk. Mengisi data hujan yang hilang dengan metode reciprocal dihitung dengan menggunakan software Microsoft Excel. Melakukan perhitungan uji konsisitensi menggunakan kurva massa ganda (double mass curve). Menghitung hujan wilayah menggunakan metode rerata aritmatik. Menghitung parameter S, Cv, Cs, Ck untuk menentukan jenis sebaran data yang sesuai dengan data hujan. Melakukan perhitungan hujan kala ulang dengan menggunakan distribusi Log Pearson III. Mencocokan uji distribusi sebaran dengan metode Smimov-Kolmogorov. Melakukan perhitungan hujan efektif untuk menghitung distribusi hujan dengan metode Mononobe. Menghitung debit hujan dengan menggunakan metode rasional. Setelah diketahui debit ini kemudian dilakukan perhitungan kebutuhan domestik guna mencukupi kebutuhan air di Desa Sambirejo Kabupaten Sragen.

\section{HASIL DAN PEMBAHASAN}

\section{Uji Konsistensi Data Hujan}

Pada penelitian ini uji konsistensi data hujan dilakukan pada 2 stasiun hujan yang digunakan pada penelitian ini, yaitu Stasiun Batujamus, dan Stasiun Munggur. Uji konsistensi menggunakan metode kurva massa ganda dengan membuat grafik antara sumbu X yaitu kumulatif hujan tahunan setiap stasiun hujan dan sumbu $\mathrm{Y}$ yaitu kumulatif hujan rerata 2 stasiun hujan. Berikut ini adalah hasil perhitungan kumulatif hujan tahunan ditampilkan pada tabel 1 dan hasilnya ditunjukkan pada gambar 1:

Tabel 1. Hasil Perhitungan Hujan Kumulatif

\begin{tabular}{ccccc}
\hline \multirow{2}{*}{ Tahun } & \multicolumn{2}{c}{ Stasiun } & Kumulatif \\
\cline { 2 - 4 } & Batujamus & Munggur & & $\begin{array}{c}\text { Rerata } \\
\text { Rerata }\end{array}$ \\
\hline 2001 & 2057 & 2139 & 2098 & 2098 \\
\hline 2002 & 1544 & 1419 & 1481 & 3579 \\
\hline 2003 & 1730 & 1130 & 1430 & 5010 \\
\hline 2004 & 2106 & 1674 & 1890 & 6900 \\
\hline 2005 & 2039 & 1696 & 1868 & 8767 \\
\hline 2006 & 1701 & 1815 & 1758 & 10525 \\
\hline 2007 & 4397 & 2848 & 3623 & 14148 \\
\hline 2008 & 3898 & 2311 & 3105 & 17252 \\
\hline 2009 & 4204 & 2627 & 3416 & 20668 \\
\hline 2010 & 6066 & 3302 & 4684 & 25352 \\
\hline 2011 & 4112 & 2376 & 3244 & 28596 \\
\hline
\end{tabular}




\begin{tabular}{lllll}
\hline 2012 & 3866 & 2233 & 3050 & 31645 \\
\hline 2013 & 5728 & 3077 & 4403 & 36048 \\
\hline 2014 & 3884 & 2808 & 3346 & 39394 \\
\hline 2015 & 4718 & 3107 & 3912 & 43306 \\
\hline
\end{tabular}

Berdasarkan tabel 1. dapat dibentuk menjadi grafik yang ditampilkan pada gambar 1 berikut

Gambar1. Grafik Uji Validitas Kurva Massa Ganda

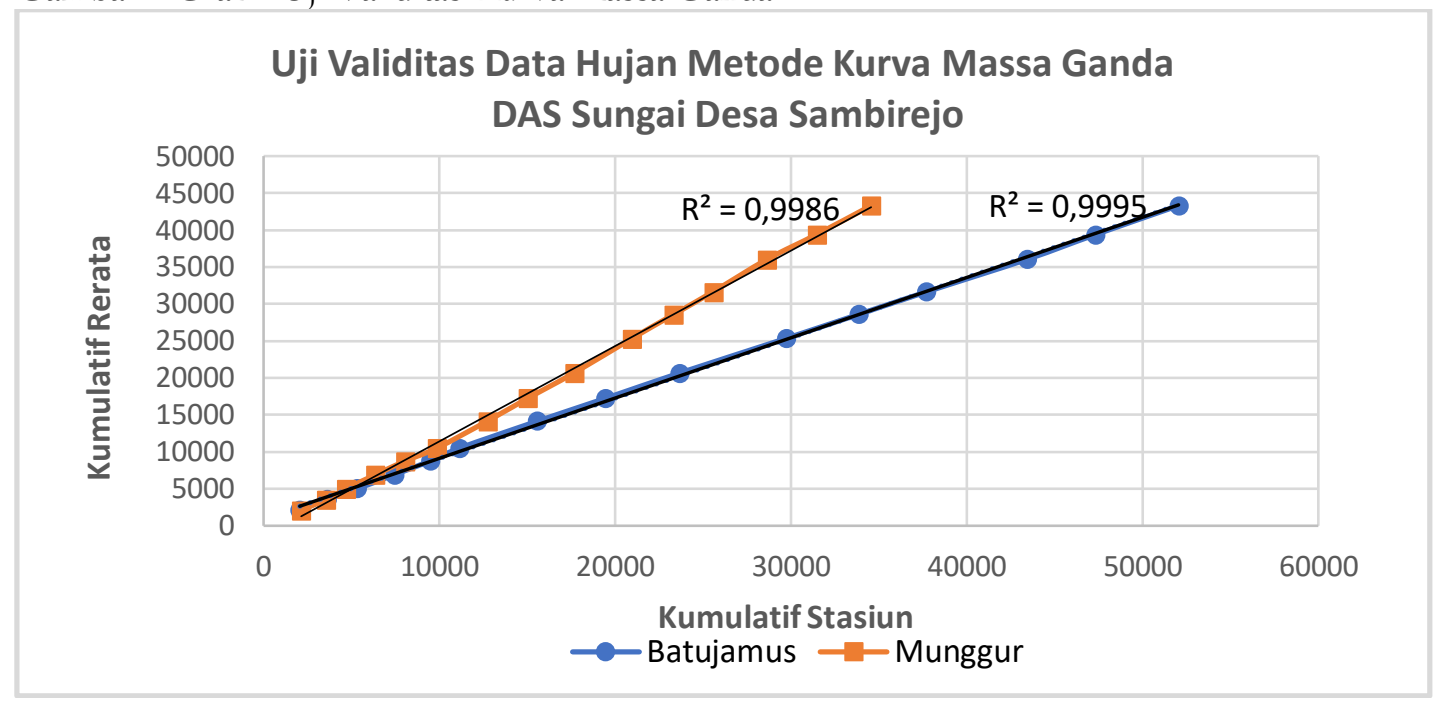

Gambar 1 didapat nilai $\mathrm{R}^{2}$ yang diperoleh dari data hujan adalah 0,99 atau mendekati 1 (satu). Hal tersebut menunjukkan data hujan dari ketiga stasiun tersebut linear atau konsisten

\section{Hujan Wilayah}

Dalam penelitian ini, untuk perhitungan hujan wilayah menggunakan metode Rerata Aritmatik berdasarkan stasiun hujan acuan yang digunakan untuk mencari rerata maksimum. Berikut ini adalah hasil perhitungan hujan wilayah yang ditampilkan pada tabel 2 dan hujan wilayah 2 harian pada tabel 3:

Tabel 2. Hujan Wilayah Harian Maksimum Tahunan

\begin{tabular}{|c|c|c|c|c|c|c|c|c|c|}
\hline \multirow{2}{*}{ Tahun } & \multicolumn{4}{|c|}{ Acuan Stasiun Batujamus } & \multicolumn{4}{|c|}{ Acuan Stasiun Munggur } & \multirow{2}{*}{$\begin{array}{l}\text { P Wil } \\
\text { Maks }\end{array}$} \\
\hline & Batujamus & Tanggal & Munggur & P Wil & Batujamus & Tanggal & Munggur & P Wil & \\
\hline 2001 & 84 & $18 \mathrm{Jan}$ & 79 & 82 & 84 & $18 \mathrm{Jan}$ & 79 & 82 & 82 \\
\hline 2002 & 86 & 16 Des & 45 & 66 & 19 & 24 Mar & 75 & 47 & 66 \\
\hline 2003 & 98 & 4 Nov & 45 & 72 & 60 & 22 Jan & 58 & 59 & 72 \\
\hline 2004 & 80 & $23 \mathrm{Nov}$ & 46 & 63 & 75 & $30 \mathrm{Okt}$ & 66 & 71 & 71 \\
\hline 2005 & 80 & $7 \mathrm{Jul}$ & 75 & 78 & 80 & $7 \mathrm{Jul}$ & 75 & 78 & 78 \\
\hline 2006 & 75 & $4 \mathrm{Mei}$ & 10 & 43 & 18 & 26 Des & 68 & 43 & 43 \\
\hline 2007 & 205 & $26 \mathrm{Des}$ & 200 & 203 & 205 & 26 Des & 200 & 203 & 203 \\
\hline 2008 & 175 & $14 \mathrm{Nov}$ & 90 & 133 & 125 & $31 \mathrm{Jan}$ & 150 & 138 & 138 \\
\hline 2009 & 317 & 31 Jan & 155 & 236 & 317 & $31 \mathrm{Jan}$ & 155 & 236 & 236 \\
\hline 2010 & 210 & $19 \mathrm{Okt}$ & 92 & 151 & 61 & $17 \mathrm{Mar}$ & 170 & 116 & 151 \\
\hline 2011 & 200 & $2 \mathrm{Mei}$ & 65 & 133 & 175 & $24 \mathrm{Apr}$ & 135 & 155 & 155 \\
\hline 2012 & 269 & $19 \mathrm{Nov}$ & 62 & 166 & 161 & 2 Jan & 152 & 157 & 166 \\
\hline 2013 & 188 & 1 Jan & 70 & 129 & 121 & $20 \mathrm{Apr}$ & 145 & 133 & 133 \\
\hline 2014 & 171 & $21 \mathrm{Apr}$ & 0 & 86 & 106 & $20 \mathrm{Apr}$ & 156 & 131 & 131 \\
\hline 2015 & 287 & $16 \mathrm{Apr}$ & 271 & 279 & 287 & $16 \mathrm{Apr}$ & 271 & 279 & 279 \\
\hline
\end{tabular}


Tabel 3. Hujan Wilayah 2 Harian Maksimum Tahunan

\begin{tabular}{|c|c|c|c|c|c|c|c|c|c|}
\hline \multirow{2}{*}{ Tahun } & \multicolumn{4}{|c|}{ Acuan Stasiun Batujamus } & \multicolumn{4}{|c|}{ Acuan Stasiun Munggur } & \multirow{2}{*}{$\begin{array}{l}\text { P Wil } \\
\text { Maks }\end{array}$} \\
\hline & Batujamus & Tanggal & Munggur & P Wil & Batujamus & Tanggal & Munggur & P Wil & \\
\hline 2001 & 113 & 18-19 Jan & 108 & 111 & 113 & 18-19 Jan & 108 & 111 & 111 \\
\hline 2002 & 95 & 26-27 Jan & 45 & 70 & 44 & 24-25 Mar & 81 & 63 & 70 \\
\hline 2003 & 100 & $16-17 \mathrm{Nov}$ & 36 & 68 & 77 & 21-22 Jan & 64 & 71 & 71 \\
\hline 2004 & 131 & 12-13 Mar & 58 & 95 & 85 & 20-21 Sep & 80 & 82 & 95 \\
\hline 2005 & 125 & $20-21 \mathrm{Nov}$ & 83 & 104 & 80 & 6-7 Jul & 99 & 90 & 104 \\
\hline 2006 & 105 & $26-27 \mathrm{Feb}$ & 66 & 86 & 18 & 26-27 Des & 132 & 75 & 86 \\
\hline 2007 & 325 & 3-4 Des & 107 & 216 & 275 & 26-27 Des & 200 & 238 & 238 \\
\hline 2008 & 290 & 23-24 Mar & 82 & 186 & 204 & 30-31 Jan & 182 & 193 & 193 \\
\hline 2009 & 361 & 4-5 Mar & 88 & 225 & 332 & 30-31 Jan & 168 & 250 & 250 \\
\hline 2010 & 258 & 18-19 Mar & 86 & 172 & 169 & 17-18 Mar & 202 & 186 & 186 \\
\hline 2011 & 375 & 1-2 Mei & 170 & 273 & 375 & 1-2 Mei & 170 & 273 & 273 \\
\hline 2012 & 272 & $19-20 \mathrm{Nov}$ & 62 & 167 & 161 & 2-3 Jan & 152 & 157 & 167 \\
\hline 2013 & 301 & $19-20 \mathrm{Nov}$ & 145 & 223 & 184 & 14-15 Des & 281 & 233 & 233 \\
\hline 2014 & 277 & 20-21 Apr & 156 & 217 & 65 & 18-19 Jun & 168 & 117 & 217 \\
\hline 2015 & 359 & $15-16 \mathrm{Apr}$ & 339 & 349 & 359 & $15-16 \mathrm{Apr}$ & 339 & 349 & 349 \\
\hline
\end{tabular}

\section{Analisis Frekuensi}

Berdasarkan analisis frekuensi didapatkan hasil pencocokan jenis distribusi hujan menggunakan pemilihan distribusi sebaran yang ditampilkan pada tabel 4:

Tabel 4. Hasil Pemilihan Jenis Distribusi Sebaran

\begin{tabular}{cccccc}
\hline No & $\begin{array}{c}\text { Jenis } \\
\text { Distribusi }\end{array}$ & & Syarat & $\begin{array}{c}\text { Hasil } \\
\text { Perhitungan }\end{array}$ & Keputusan \\
\hline 1 & Normal & $\mathrm{Cs}=0$ & & 0,71 & Tidak \\
& & $\mathrm{Ck}=3$ & $-0,06$ & Tidak \\
\hline 2 & Log Normal & $\mathrm{Cs}=0$ & $\mathrm{Cv}^{3}+3 \mathrm{Cv}=1.50$ & $-0,19$ & Tidak \\
& & $\mathrm{Ck}=3 \quad \mathrm{Cv}^{8}+6 \mathrm{Cv}^{6}+15 \mathrm{Cv}^{4}+$ & $-0,79$ & Tidak \\
& & \multicolumn{2}{c}{$16 \mathrm{Cv}^{2}+3=7.27$} & 0,71 & Tidak \\
\hline 3 & Gumbell & $\mathrm{Cs}=1,14$ & $-0,06$ & Tidak \\
\hline 4 & & $\mathrm{Ck}=5,4$ & OK \\
\hline
\end{tabular}

\section{Uji Kecocokan}

Uji kecocokan terhadap jenis distribusi sebaran yaitu menggunakan Log Pearson Tipe III. Pada penelitian ini, uji kecocokan menggunakan uji Smirnov-Kolmogorov dengan tingkat signifikansi/ketelitian sebesar 5\%. Berikut adalah perhitungan uji Smirnov-Kolmogorov ditampilkan pada tabel 5.

Tabel 5. Perhitungan Uji Smirnov-Kolmogorov

\begin{tabular}{cccccccccc}
\hline Tahun & $\boldsymbol{R} 24$ & $\boldsymbol{x}$ & $\boldsymbol{m}$ & $\boldsymbol{P}(\boldsymbol{x})=\boldsymbol{m} /(\boldsymbol{n}+\mathbf{1})$ & $\boldsymbol{P}(\boldsymbol{x}<)$ & $\begin{array}{c}\boldsymbol{f}(\boldsymbol{t})= \\
(\boldsymbol{x}-\overline{\mathbf{x}}) / \boldsymbol{s}\end{array}$ & $\boldsymbol{P}^{\prime}(\boldsymbol{x})$ & $\boldsymbol{P}^{\prime}(\boldsymbol{x}<)$ & $\Delta$ \\
\hline 2001 & 82 & 279 & 1 & 0,07 & 0,93 & 2,14 & 0,02 & 0,98 & 0,05 \\
\hline 2002 & 66 & 236 & 2 & 0,13 & 0,88 & 1,51 & 0,07 & 0,93 & 0,06 \\
\hline 2003 & 72 & 203 & 3 & 0,19 & 0,81 & 1,02 & 0,15 & 0,85 & 0,03 \\
\hline 2004 & 71 & 166 & 4 & 0,25 & 0,75 & 0,47 & 0,32 & 0,68 & $-0,07$ \\
\hline 2005 & 78 & 155 & 5 & 0,31 & 0,69 & 0,32 & 0,38 & 0,62 & $-0,06$ \\
\hline 2006 & 43 & 151 & 6 & 0,38 & 0,63 & 0,26 & 0,40 & 0,60 & $-0,02$ \\
\hline 2007 & 203 & 138 & 7 & 0,44 & 0,56 & 0,06 & 0,48 & 0,52 & $-0,04$ \\
\hline 2008 & 138 & 133 & 8 & 0,50 & 0,50 & $-0,01$ & 0,50 & 0,50 & 0,00
\end{tabular}




\begin{tabular}{|c|c|c|c|c|c|c|c|c|c|}
\hline 2009 & 236 & 131 & 9 & 0,56 & 0,44 & $-0,03$ & 0,51 & 0,49 & 0,05 \\
\hline 2010 & 151 & 82 & 10 & 0,63 & 0,38 & $-0,76$ & 0,78 & 0,22 & $-0,15$ \\
\hline 2011 & 155 & 78 & 11 & 0,69 & 0,31 & $-0,82$ & 0,79 & 0,21 & $-0,11$ \\
\hline 2012 & 166 & 72 & 12 & 0,75 & 0,25 & $-0,91$ & 0,82 & 0,18 & $-0,07$ \\
\hline 2013 & 133 & 71 & 13 & 0,81 & 0,19 & $-0,92$ & 0,82 & 0,18 & $-0,01$ \\
\hline 2014 & 131 & 66 & 14 & 0,88 & 0,13 & $-1,00$ & 0,84 & 0,16 & 0,03 \\
\hline \multirow[t]{2}{*}{2015} & 279 & 43 & 15 & 0,94 & 0,06 & $-1,33$ & 0,91 & 0,09 & 0,03 \\
\hline & & $\overline{\boldsymbol{x}}$ & 113 & & & & & $\Delta$ maks & 0,06 \\
\hline
\end{tabular}

Berdasarkan Tabel 6, didapatkan nilai $\Delta$ maks $=0,064$ dan berdasarkan untuk jumlah data (n) $=15$ dan tingkat signifikansi $(\alpha)=5 \%$ didapatkan nilai $\Delta$ kritis $=0,34$. Karena nilai $\Delta$ maks $(0,06)<\Delta$ kritis $(0,34)$, maka distribusi Log Pearson Tipe III dapat diterima.

\section{Hujan Kala Ulang}

Hujan kala ulang dihitung menggunakan metode Log Pearson Tipe III sebagaimana telah ditentukan berdasarkan keputusan pemilihan jenis distribusi. Perhitungan distribusi log pearson tipe III disajikan pada tabel 6 dan perhitungan hujan kala ulang pada tabel 7.

Tabel 6. Perhitungan Distribusi Log Pearson Tipe III

\begin{tabular}{cccc}
\hline No & Tahun & $\boldsymbol{R} 24(\boldsymbol{x})$ & $\boldsymbol{X}(\log \boldsymbol{x})$ \\
\hline 1 & 2001 & 82 & 4,40 \\
\hline 2 & 2002 & 66 & 4,18 \\
\hline 3 & 2003 & 72 & 4,27 \\
\hline 4 & 2004 & 71 & 4,26 \\
\hline 5 & 2005 & 78 & 4,35 \\
\hline 6 & 2006 & 43 & 3,76 \\
\hline 7 & 2007 & 203 & 5,31 \\
\hline 8 & 2008 & 138 & 4,92 \\
\hline 9 & 2009 & 236 & 5,46 \\
\hline 10 & 2010 & 151 & 5,02 \\
\hline 11 & 2011 & 155 & 5,04 \\
\hline 12 & 2012 & 166 & 5,11 \\
\hline 13 & 2013 & 133 & 4,89 \\
\hline 14 & 2014 & 131 & 4,88 \\
\hline 15 & 2015 & 279 & 5,63 \\
\hline & & Jumlah & 71,49 \\
\cline { 3 - 3 } & & $\bar{x}$ & 4,77 \\
\cline { 2 - 3 } & & $\mathrm{S}$ & 0,53 \\
\cline { 2 - 3 } & $\mathrm{Cv}$ & 0,11 \\
\cline { 2 - 3 } & $\mathrm{Cs}$ & $-0,19$ \\
\cline { 3 - 4 } & $\mathrm{Ck}$ & $-0,79$ \\
\cline { 3 - 4 } & & & \\
& & &
\end{tabular}

Tabel 7. Hasil Perhitungan Hujan Kala Ulang

\begin{tabular}{ccccc}
\hline Kala Ulang & $\boldsymbol{K}$ & $\boldsymbol{k} \cdot \mathbf{S}$ & $\overline{\boldsymbol{x}}+\boldsymbol{k} \cdot \mathbf{S}$ & $\mathbf{R t}(\mathbf{m m} / \mathbf{h r})$ \\
\hline 5 & 0,86 & 0,46 & 5,23 & 186 \\
\hline 20 & 1,56 & 0,83 & 5,60 & 270 \\
\hline 50 & 1,97 & 1,05 & 5,82 & 336 \\
\hline
\end{tabular}




\section{Hujan Efektif}

Hujan efektif dihitung dengan mengalikan hujan kala ulang dan hujan wilayah 2 harian maksimum tahunan dengan koefisien limpasan yang ditentukan berdasarkan tata guna lahan. Berikut adalah perhitungan hujan efektif ditampilkan pada tabel 8 .

Tabel 8. Hasil Perhitungan Hujan Efektif

\begin{tabular}{|c|c|c|c|}
\hline Hujan & & $\mathbf{P}(\mathrm{mm})$ & P Eff (mm) \\
\hline \multirow{3}{*}{ Kala Ulang } & 5 & 186 & 93,16 \\
\hline & 20 & 270 & 134,90 \\
\hline & 50 & 336 & 168,14 \\
\hline \multirow{15}{*}{2 Harian Maksimum Tahunan } & 2001 & 111 & 55,28 \\
\hline & 2002 & 70 & 35,00 \\
\hline & 2003 & 71 & 35,25 \\
\hline & 2004 & 95 & 47,25 \\
\hline & 2005 & 104 & 52,00 \\
\hline & 2006 & 86 & 42,75 \\
\hline & 2007 & 238 & 118,75 \\
\hline & 2008 & 193 & 96,50 \\
\hline & 2009 & 250 & 125,00 \\
\hline & 2010 & 186 & 92,75 \\
\hline & 2011 & 273 & 136,25 \\
\hline & 2012 & 167 & 83,50 \\
\hline & 2013 & 233 & 116,25 \\
\hline & 2014 & 217 & 108,25 \\
\hline & 2015 & 349 & 174,48 \\
\hline
\end{tabular}

\section{Pola Agihan Hujan}

Dalam penelitian ini, waktu konsentrasi dihitung menggunakan rumus Kirpich dengan data yang tersedia.

Dengan data masukkan tersebut, dapat dihitung waktu konsentrasi $\left(t_{c}\right)$ :

$$
\begin{aligned}
t_{c} & =G \cdot k \cdot\left(L / . S^{0,5}\right) 0,77 \\
& =0,06628 \times 1,0\left(16,1 / 0,015^{0,5}\right)^{0,77} \\
& =2,837 \mathrm{jam} \\
& \approx 3 \mathrm{jam}
\end{aligned}
$$

\section{Perhitungan Debit}

Dalam penelitian ini, perhitungan debit dilakukan menggunakan metode rasional dengan koefisien pengaliran (Nilai C) dengan daerah yang memiliki karakteristik perumputan, perumahan, jalan, pertamanan dan kuburan maka digunakan koefisien pengaliran rata-rata sebesar 0,4711. Berikut adalah hasil perhitungan debit yang ditampilkan pada tabel 9.

Tabel 9. Hasil Perhitungan Debit

\begin{tabular}{ccc}
\hline No & Tahun & $\left.\boldsymbol{R} 24(\boldsymbol{Q}) \boldsymbol{m}^{\mathbf{3}} / \boldsymbol{d e t i k}\right)$ \\
\hline 1 & 2001 & 200,57 \\
\hline 2 & 2002 & 126,656 \\
\hline 3 & 2003 & 127,561 \\
\hline 4 & 2004 & 170,986 \\
\hline 5 & 2005 & 188,175 \\
\hline 6 & 2006 & 154,701 \\
\hline 7 & 2007 & 429,726 \\
\hline
\end{tabular}




\begin{tabular}{ccc}
\hline 8 & 2008 & 349,209 \\
\hline 9 & 2009 & 452,343 \\
\hline 10 & 2010 & 335,638 \\
\hline 11 & 2011 & 493,054 \\
\hline 12 & 2012 & 302,165 \\
\hline 13 & 2013 & 420,679 \\
\hline 14 & 2014 & 391,729 \\
\hline 15 & 2015 & 631,386 \\
\hline
\end{tabular}

\section{Analisis Kebutuhan Air Domestik}

Kebutuhan air domestik dapat dicari dengan cara menghitung debit berdasarkan metode rasional, setelah itu kita hitung jumlah kehilangan air sebesar 40\% (Hermantoro, 2011) dari debit metode rasional. Selanjutnya dihitung debit tersedia dengan debit metode rasional dikurangi kehilangan air sebesar 40\%. Berikut adalah perhitungan hujan efektif ditampilkan pada tabel 10.

Tabel 10. Hasil Perhitungan Kebutuhan Domestik

\begin{tabular}{cccc}
\hline Tahun & $\begin{array}{c}\text { Debit } \\
\text { (m3/detik) }\end{array}$ & $\begin{array}{c}\text { Hilang } \\
(\mathbf{m} 3 \text { detik) }\end{array}$ & Tersedia (m3/detik) \\
\hline 2001 & 200,057 & 80,023 & 120,034 \\
\hline 2002 & 126,656 & 50,662 & 75,994 \\
\hline 2003 & 127,561 & 51,024 & 76,536 \\
\hline 2004 & 170,986 & 68,394 & 102,591 \\
\hline 2005 & 188,175 & 75,270 & 112,905 \\
\hline 2006 & 154,701 & 61,881 & 92,821 \\
\hline 2007 & 429,726 & 171,890 & 257,835 \\
\hline 2008 & 349,209 & 139,683 & 209,525 \\
\hline 2009 & 452,343 & 180,937 & 271,406 \\
\hline 2010 & 335,638 & 134,255 & 201,383 \\
\hline 2011 & 493,054 & 197,222 & 295,832 \\
\hline 2012 & 302,165 & 120,866 & 181,299 \\
\hline 2013 & 420,679 & 168,272 & 252,407 \\
\hline 2014 & 391,729 & 156,692 & 235,037 \\
\hline 2015 & 631,386 & 252,554 & 378,832 \\
\hline
\end{tabular}

\section{KESIMPULAN}

Berdasarkan hasil penelitian dan pembahasan, maka dapat disimpulkan bahwa dengan debit yang tersedia embung di Desa Sambirejo Kabupaten Sragen mampu mencukupi kebutuhan domestik warga dari tahun 2001 hingga 2015. Dan dengan proyeksi hingga tahun 2025 kebutuhan domestik warga bisa tercukupi.

\section{DAFTAR PUSTAKA}

Anonim. 2013. Wikipedia. https://id.wikipedia.org/wiki/Embung. Diakses tanggal 29 Maret 2017 pukul 15.54 WIB.

Daulay Nurhamimah, dan Terumajaya. 2015. Pemanenan Air Hujan (Rain Water Harvesting) Sebagai Alternatif Pengolaban Sumberdaya Air Di Rumah Tangga. Departemen Teknik Sipil, Universitas Sumatra Utara. Medan.

Departemen Pekerjaan Umum. 1989. Metode Perhitungan Debit Banjir SK SNI M-18-1989-F. Yayasan Lembaga Penyelidikan Masalah Bangunan. Bandung.

Hermantoro. 2011. Peningkatan Efektivitas Tampungan Embung Melalui Perbaikan Bentuk Dan Dimensi. Fakultas Teknologi Pertanian, Kampus Pusat Instiper. Yogyakarta. 
J. Kindler and C.S. Russel, 1984. Modeling Water Demands. Academic Press Inc. London.

Lembaga Pendidikan Kader Gerakan Pramuka Tingkat Nasional (Lemdikanas). 2005. Panduan Khusus Pembinaan Pramuka Mabir Tingkat Dasar. Kwartir Cabang 1205 Yogyakarta.

Nuansah Fidiawan, 2008. Perencanaan Embung Pusporenggo Kabupaten Boyolali, Jawa Tengah. Skripsi. Jurusan

Teknik Sipil, Fakultas Teknik, Universitas Diponegoro.

Nuansah Fidiawan, 2013. Penelusuran Banjir di Sungai Wuryantoro Sub DAS Bengawan Solo 3. Skripsi. Jurusan

Teknik Sipil, Fakultas Teknik, Universitas Sebelas Maret Surakarta.

Peraturan Menteri Negara Lingkungan Hidup No. 12 Tahun 2009 tentang Pemanfaatan Air Hujan. Jakarta : BLH

Puri Ayu. 2011. Kekeringan. http://ayouk91.blogspot.co.id/2011/06/kekeringan.html. Diakses tanggal 26 September 2017 pukul 19.28 WIB.

Rapar, Sharon Marthina, Tiny Manaroma, Elevine Wuisan dan Alex Binilang. 2014. Analisis Debit Banjir Sungai

Tondano menggunakan Metode HSS Gama I dan HSS Limantara. Jurnal Sipil Statik. Volume 2, No. 1, (2014) ISSN : 2337-6732

Soewarno, 1995. Hidrologi Aplikasi Metode Statistik untuk Analisis Data. Bandung : Nova.

Suripin. 2004. Sistem Drainase Perkotaan yang Berkelanjutan. Andi Offset. Yogyakarta.

Taufik Imam Rohadi. 2014. PIONER Science, Energy, and Technology. http://pioner21.blogspot.co.id/2014/09/makalah-lingkungan-air-hujan-jangan.html. Diakses tanggal 24 Maret 2017 pukul 19.36 WIB.

Triatmojo, Bambang. Hidrologi Terapan. 2008. Beta Offset. Yogyakarta.

Triatmojo, Bambang. Hidrologi Terapan. 2009. Beta Offset. Yogyakarta. 